\title{
CLIMATE CHANGES AND TECHNOLOGICALADVANCES: IMPACTS ON SUGARCANE PRODUCTIVITY IN TROPICAL SOUTHERN BRAZIL
}

\author{
Júlia Ribeiro Ferreira Gouvêa ${ }^{1}$; Paulo Cesar Sentelhas²*; Samuel Thomazella Gazzola; \\ Marcelo Cabral Santos² \\ ${ }^{1}$ USP/ESALQ - Programa de Pós-Graduação em Física do Ambiente Agrícola \\ ${ }^{2}$ USP/ESALQ - Depto. de Engenharia Rural, Av. Pádua Dias, 11 - 13418-900 - Piracicaba, SP - Brasil. \\ ${ }^{3}$ COSAN - Usina Costa Pinto, Bairro Costa Pinto, 13418-000 - Piracicaba, SP - Brasil. \\ *Corresponding author <pcsentel@esalq.usp.br>
}

\begin{abstract}
The climatic projections for this century indicate the possibility of severe consequences for human beings, especially for agriculture where adverse effects to productivity of crops and to agribusiness as a whole may occur. An agrometeorological model was used to estimate sugarcane yield in tropical southern Brazil, based on future A1B climatic scenarios presented in the fourth Intergovernmental Panel on Climate Change report, in 2007. Sugarcane yield was evaluated for 2020, 2050, and 2080 considering the possible impacts caused by changes in temperature, precipitation, sunshine hours and $\mathrm{CO}_{2}$ concentration in the atmosphere, as well as technological advances. Increasingly higher temperatures will cause an increase of the potential productivity (PP), since this variable positively affects the efficiency of the photosynthetic processes of C4 plants. Changes in solar radiation and rainfall, however, will have less impact. PP will increase by $15 \%$ in relation to the present condition in 2020, by $33 \%$ in 2050 and by $47 \%$ in 2080. Regarding the actual productivities (AP), the increase observed in PP will compensate for the negative effect of the projected increase in water deficit. AP will increase by $12 \%$ in relation to the present condition in 2020, by $32 \%$ in 2050 and by $47 \%$ in 2080 . The increase in sugarcane productivity resulting from the projected scenarios will have important impacts on the sugarcane sector.
\end{abstract}

Key words: global warming, water balance, agrometeorological model, sugarcane yield

\section{MUDANÇAS CLIMÁTICAS E AVANÇOTECNOLÓGICO: IMPACTOS NA PRODUTIVIDADE DA CANA-DE-AÇÚCARNA REGIÃO CENTRO-SULDOBRASIL}

\begin{abstract}
RESUMO: As projeções climáticas para este século indicam a possibilidade de graves conseqüências para a humanidade, especialmente para a agricultura, com efeitos adversos nas produtividades das culturas e no agronegócio como um todo. Neste estudo, foi utilizado um modelo agrometeorológico para estimar a produtividade da cana-de-açúcar na região de Piracicaba, SP, Brasil, baseado nos cenários futuros do clima A1B, apresentados no quarto relatório do Painel Intergovernamental sobre Mudanças Climáticas, de 2007. A produtividade da cana-de-açúcar foi avaliada nos anos de 2020, 2050 e 2080, levando-se em consideração as possíveis alterações de temperatura, precipitação, insolação e concentração de $\mathrm{CO}_{2}$ na atmosfera, assim como os avanços tecnológicos. O aumento da temperatura acarretará no aumento da produtividade potencial (PP), já que essa variável afeta positivamente a eficiência do processo fotossintético das plantas C4; entretanto, as alterações na radiação solar e na chuva terão menores impactos na produtividade. A PP aumentará cerca de 15\% em relação à condição atual em 2020, de 33\% em 2050 e de $47 \%$ em 2080. Com relação à produtividade real (AP), o aumento da PP compensará o efeito negativo causado pelo aumento projetado para o déficit hídrico. A AP aumentará cerca de $12 \%$ em relação à condição atual em 2020, de 32\% em 2050 e de 47\% em 2080. O aumento da produtividade da canade-açúcar observado na ocorrência dos cenários futuros avaliados terá impactos importantes no setor canavieiro.

Palavras-chave: aquecimento global, balanço hídrico, modelo agrometeorológico, rendimento da canade-açúcar
\end{abstract}




\section{INTRODUCTION}

Global warming refers to an increase in global temperatures. Natural events and human activities are contributing to an increase in average global temperatures. This is caused mainly by increases in the concentration of "greenhouse" gases such as carbon dioxide, methane and nitrous oxide. The global increases in carbon dioxide concentration are due primarily to fossil fuel combustion and land-use change, while those of methane and nitrous oxide are primarily due to agriculture (Simon \& DeFries, 1992; Marengo, 2006; Cerri et al., 2007). Global warming is projected to have significant impacts on conditions affecting agriculture, including changes in temperature, rainfall and solar radiation patterns. These conditions determine the production capacity of the land. Rising carbon dioxide levels would also have effects, both detrimental and beneficial, on crop yields. The overall effect of climate change on agriculture will depend on the balance of these effects (Fischer et al., 2002).

Agriculture is the economic activity that most depends upon the weather and climate conditions (Assad et al., 2004). The climate affects the growth and development of plants, as well as the pests that may harm the crops. Any change in the climate will have impact on crop growth and development, as well as the relationship of the plants with microorganisms. One of the best ways to study the impact of climate change on agriculture, more specifically on crop yield, is by applying crop simulation models (Challinor et al, 2005). These models are tools that simulate the influence of climatic conditions on the growth, development and productivity of crops. Their output enables environmental risks and production costs to be minimized, which may be an important aid to the development of public policies for decision taking (Pereira et al., 2002). Among the available crop simulation models, the AgroEcological Zones model, based on the DeWit methodology and presented by Doorenbos \& Kassam (1994), has proved to be a very useful and accurate way to estimated potential productivity (Fischer et al., 2002). Also, when potential productivity is penalized by water deficits, during some or all crop development phases, this model is able to estimate actual productivity with high accuracy (Rolim et al., 1998; Marin et al., 2008).

Nowadays, concerns about environmental matters, fuel reserves and expected future increases in the price of fossil fuels are causing several changes in the Brazilian energy sector. The search for renewable and less polluting energy sources benefits sugarcane production, since alcohol is an alternative that may substitute fossil fuels (Goldemberg \& Lucon, 2007).
This work used a crop simulation model to determine the potential productivity changes and climatic risks associated with sugarcane production under scenarios of expected climate change and technological advances. The climatic data from an eighty-year period for the Piracicaba region, State of São Paulo, Brazil, were modified according to the prognoses for the fourth IPCC report and used to quantify the possible impacts of climate change on sugarcane crop productivity. Historical sugarcane yield data for the state of São Paulo was also evaluated to quantify the effect of technological advances in the future scenarios.

\section{MATERIAL AND METHODS}

\section{Location and weather data}

This study was carried out for the Piracicaba region, State of São Paulo, Brazil, which is one of the main sugarcane production regions of the state. The climate of the area is tropical (wet summer and dry winter). Weather data were taken from the database of a conventional agrometeorological station located at the following coordinates: $22^{\circ} 42^{\prime} \mathrm{S}$; $47^{\circ} 38^{\prime} \mathrm{W}$; and 546 $\mathrm{m}$ asl, in Piracicaba, for the period 1927 to 2006. Data were considered in 10-day time intervals, and the variables included in this study were: air temperature (maximum, minimum and mean), sunshine hours, and rainfall, which were used to estimate potential evapotranspiration, climatological water balance, crop water balance and sugarcane potential and actual productivities.

\section{Sugarcane potential productivity model}

The crop potential productivity (PP) was estimated by the Agro-Ecological Zones model (AZM) (Doorenbos \& Kassam, 1994). This model estimates the maximum yield of a crop which would be obtained with a highly productive variety, very well adapted to the respective growth environment; with water, nutritional and phytosanitary requirements supplied, and with the productivity conditioned only by the genetic characteristics of the crop and the environmental conditions (solar radiation, photoperiod and air temperature).

The potential productivity of the crop is given by the gross productivity of the dry matter in a standard crop, taking into consideration some coefficients related to the characteristics of the crop. The crop production varies according to the species, type of carbon fixation metabolism and temperature, due to climatic adaptations.

The following equations describe the procedures for estimating PP, using the AZM (Barbieri \& Tuon, 1992):

$$
\mathrm{PP}=\mathrm{PPG} * \mathrm{C}_{\mathrm{LAI}} * \mathrm{C}_{\mathrm{R}} * \mathrm{C}_{\mathrm{H}} * \mathrm{C}_{\mathrm{W}} * \mathrm{CD}\left[\mathrm{kg} \mathrm{DM} \mathrm{ha}^{-1}\right]
$$


where: PPG is the gross potential productivity, in dry mass (kg DM ha ${ }^{-1}$ ) of a standard crop; $\mathrm{C}_{\mathrm{LAI}}$ is the correction for the leaf area index of the specific crop; $C_{R}$ is the respiration coefficient, to account for losses by the respiration process; $\mathrm{C}_{\mathrm{H}}$ is the harvest index for the specific crop; $\mathrm{C}_{\mathrm{w}}$ is the correction coefficient to consider the weight of the water content in the harvested product; and CD is the duration of the crop cycle (day).

The gross potential productivity is given by:

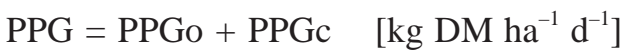

where: PPGo and PPGc are respectively the gross potential productivity obtained during overcast and clear sky conditions. These variables are given by the following expressions:

PPGo = $\left(31.7\right.$ + 5.234 Ra) cTo $(1-\mathrm{n} / \mathrm{N})\left[\mathrm{kg} \mathrm{DM} \mathrm{ha}{ }^{-1} \mathrm{~d}^{-1}\right]$

PPGc $=(107.2+8.604 \mathrm{Ra}) \mathrm{cTc} n / \mathrm{N}\left[\mathrm{kg} \mathrm{DM} \mathrm{ha}^{-1} \mathrm{~d}^{-1}\right]$

where: $\mathrm{Ra}$ is the extraterrestrial solar radiation $\left[\mathrm{MJ} \mathrm{m}{ }^{-2} \mathrm{~d}^{-1}\right.$ ]; $\mathrm{n}$ is the effective number of sunshine hours; $\mathrm{N}$ is the maximum number of sunshine hours; and cTo and cTc are the photosynthesis efficiencies during overcast and clear sky conditions, respectively. Both cTo and cTc are function of air temperature, and are given by the equations adjusted for sugarcane by Barbieri \& Tuon (1992):

a) For $\mathrm{T} \geq 16.5^{\circ} \mathrm{C}$

сTo $=-1.064+0.173 \mathrm{~T}-0.0029 \mathrm{~T}^{2}$
сTс $=-4.16+0.4325 \mathrm{~T}-0.00725 \mathrm{~T}^{2}$

b) For $\mathrm{T}<16.5^{\circ} \mathrm{C}$

cTo $=-4.16+0.4325 \mathrm{~T}-0.00725 \mathrm{~T}^{2}$

cTc $=-9.32+0.865 \mathrm{~T}-0.0145 \mathrm{~T}^{2}$

where $\mathrm{T}$ is the average air temperature during the 10 day period.

The $\mathrm{C}_{\mathrm{LAI}}$ for each 10-day period was calculated as a function of the leaf area index (LAI), which was determined for sugarcane by power-exponential functions that have accumulated degree-days (DD) as dependent variable, using a base temperature of $18^{\circ} \mathrm{C}$ (Teruel et al., 1997):

LAI $=\mathrm{e}^{-13.52}(\Sigma \mathrm{DD})^{2.788} \mathrm{e}^{-0.004023 \Sigma \mathrm{DD}} \quad$ for plant crop

$\mathrm{LAI}=\mathrm{e}^{-20.21}(\Sigma \mathrm{DD})^{3.832} \mathrm{e}^{-0.004936 \Sigma \mathrm{DD}}$ for ratoon crops where DD was calculated as the difference between average temperature and base temperature.

The LAI values for each period (i) were then used to determine $\mathrm{C}_{\mathrm{LAI}}$ by the following polynomial equation (Barbieri \& Tuon, 1992):

$\mathrm{C}_{\mathrm{LAI}_{(\mathrm{i})}}=0.0093+0.185 \mathrm{LAI}_{(\mathrm{i})}-0.0175 \mathrm{LAI}_{(\mathrm{i})}{ }^{2}$

(for LAI $\geq 5, \mathrm{C}_{\mathrm{LAI}}=0.5$ )

The respiration coefficient $\left(C_{R}\right)$ of the model was computed as a function of the average temperature ( $\mathrm{T}$ ) in the period, being $\mathrm{C}_{\mathrm{R}}=0.6$ for $\mathrm{T}<20^{\circ} \mathrm{C}$, and $\mathrm{C}_{\mathrm{R}}=$ 0.5 for $\mathrm{T} \geq 20^{\circ} \mathrm{C}$. The adopted harvest index $\left(\mathrm{C}_{\mathrm{H}}\right)$ for the sugarcane crop was 0.8 (Doorenbos \& Kassam, 1994). The water content correction $\left(C_{w}\right)$ was calculated by the following expression (Pereira et al., 2002):

$\mathrm{C}_{\mathrm{W}}=(1-0.01 \mathrm{U} \%)^{-1}$

where $\mathrm{U} \%$ is the percentage of water in the canes, taken as $80 \%$ (Doorenbos \& Kassam, 1994).

Finally, the duration of the sugarcane crop cycle (CD) was taken as 16 months or 485 days for a plant crop and 12 months or 365 days for ratoon crops, as normally observed in the Piracicaba region. The plant crop was established in March of each year and harvested in June of the next year. The ratoon crops were divided into three different cycles of maturation: early ratoon, from April to March; mid ratoon, from August to July; and late ratoon, from October to September.

\section{Estimating actual productivity as a function of wa- ter deficit}

The actual productivity (AP) for sugarcane in the context of this study refers only to water-limited yield, and does not account for fertilization levels and pest damage. The AP for sugarcane was calculated by a model that estimates the yield rate due to the potential productivity (PP) and relative water deficit, which occurs in each phase of development, according to the water deficit sensitivity index (Ky). Thus, by knowing the relation between actual and crop evapotranspiration (ETa/ETc), PP and Ky, it is possible to determine (AP) of a crop by the following equation (Barbieri \& Tuon, 1992; Doorenbos \& Kassam, 1994; Pereira et al., 2002; Marin et al., 2008):

$\mathrm{AP}=\prod_{i=1}^{n}\left\{\mathrm{PP}_{\mathrm{i}}\left[1-\mathrm{Ky}_{\mathrm{i}}\left(1-\mathrm{ETa}_{\mathrm{i}} / \mathrm{ETc}_{\mathrm{i}}\right)\right]\right\}$

\section{Potential (ETP) and crop (ETc) evapotranspiration}

The potential evapotranspiration (ETP) was estimated by the Thornthwaite method using the concept of an "effective temperature" (Camargo et al., 1999). The Thornthwaite (1948) method, which considers a standard evapotranspiration (ETp) for a thirty-day period with a twelve-hour photoperiod, was modified by 
Camargo et al. (1999) to be employed in any climatic condition. To this end, an effective temperature (Tef) is used, which considers the local thermal amplitude:

Tef $=0.36(3 *$ Tmax - Tmin $)$

where: Tmax is the maximum temperature and Tmin the minimum temperature, both in ${ }^{\circ} \mathrm{C}$. Consequently, the potential evapotranspiration is no longer underestimated in dry climate conditions or overestimated in humid environments (Camargo et al., 1999).

Crop evapotranspiration was determined by the product between ETP and crop coefficients (Kc) for each phase of the sugarcane crop, as recommended by FAO (Table 1$)$.

\section{Determination of the crop water balance}

The method of Thornthwaite \& Mather (1955) was used to process the sequential crop water balance in ten-day time steps, using the "BHcult" program made by Rolim et al. (1998) in an electronic worksheet, with the adaptations proposed by Barbieri et al. (1997). This method proposes that the variation of water storage in the soil follows an exponential function during the drying process. It considers the effective deepness of the roots, the physical characteristics of the soil, and the change in water content as a function of the balance between rainfall $(\mathrm{P})$ and crop evapotranspiration (ETc). As a result, the water balance provides estimates for the actual crop evapotranspiration (ETa), water deficit (WD), and water surplus (WS) for each period (Pereira et al., 2002). This method was adopted because it is simple and accurate enough for the pur- poses of this study, as proved by Rolim et al. (2001) and Marin et al. (2008).

\section{Calibration of the models used to estimate poten- tial and actual productivity}

The models used for estimating potential and actual productivity in this study were previously calibrated for the sugarcane crop by different authors. In this work, calibrated values of Ky were obtained from Santos et al. (2006) and Gazzola (2007), who used identical parameterizations for the AZM. The Ky values resulting from the calibration process are presented in Table 2.

Figure 1 presents the result of the calibration process obtained with data from Santos et al. (2006) and Gazzola (2007), for the Piracicaba region. A high agreement between estimated and observed actual productivity data was observed, with a slope of 1.02, and $\mathrm{R}^{2}$ of $0.83(p<0.01)$. This calibration process was made with data from a wide range of water deficit conditions, during four consecutive years with harvests from April to November of each year. The results show that the model can explain $83 \%$ of yield variation, between 60 and $130 \mathrm{t} \mathrm{ha}^{-1}$, which is a good performance for the purposes of this study.

\section{Analysis of the sugarcane productivity for the cur- rent climatic conditions}

The potential and actual sugarcane productivity data, obtained by the calibrated Agro-Ecological Zones and water deficit penalization methods, were determined for an eighty-year historic series, considering

Table 1 - Crop coefficients (Kc) for sugarcane plant and ratoon crops for different development phases. Adapted from Doorenbos \& Kassam (1994).

\begin{tabular}{ccccc}
\hline \multicolumn{2}{c}{ Plant Crop } & & \multicolumn{2}{c}{ Ratoon Crop } \\
\cline { 1 - 1 } Days of the cycle & Kc & & Days of the cycle & Kc \\
\hline $1-61$ & 0.40 & $1-61$ & 0.40 \\
$62-153$ & 0.75 & $62-153$ & 0.75 \\
$154-244$ & 1.10 & $154-244$ & 1.10 \\
$245-334$ & 1.25 & $245-334$ & 1.25 \\
$335-485$ & 0.70 & $335-365$ & 0.70 \\
\hline
\end{tabular}

Table 2 - Water deficit sensitivity index (Ky) calibrated for the sugarcane crop in different periods of development. Source: Santos et al. (2006) and Gazzola (2007).

\begin{tabular}{lccc}
\hline \multirow{2}{*}{ Phenological phase } & \multicolumn{3}{c}{ Ky } \\
\cline { 2 - 4 } & $\begin{array}{c}\text { Sugarcane plant and early } \\
\text { sugarcane ratoon }\end{array}$ & Medium sugarcane ratoon & $\begin{array}{c}\text { Late sugarcane } \\
\text { ratoon }\end{array}$ \\
\hline Sprouting and establishment & 0.75 & 0.80 & 0.70 \\
Period of high vegetative growth & 0.75 & 0.80 & 0.70 \\
Harvest formation & 0.50 & 0.70 & 0.50 \\
Maturation & 0.10 & 0.30 & 0.10 \\
\hline
\end{tabular}


the observed conditions of temperature, precipitation, sunshine hours and the current $\mathrm{CO}_{2}$ concentration in the atmosphere. This analysis was taken to be the current scenario (C0).

\section{Future climate projections for the Piracicaba region}

The climatic conditions of the scenario A1B (IPCC, 2007) were then used in the simulations. This scenario was adopted because it presents the most rational use of energy sources, combining fossil and non-fossil fuels. Changes of temperature for A1B scenario range from 1.7 to $4.4^{\circ} \mathrm{C}$ for 2100 . It also indicates that there may be -5 to $+5 \%$ variations in rainfall during summertime, and -5 to $-10 \%$ variations during wintertime for the Piracicaba region (IPCC, 2007).

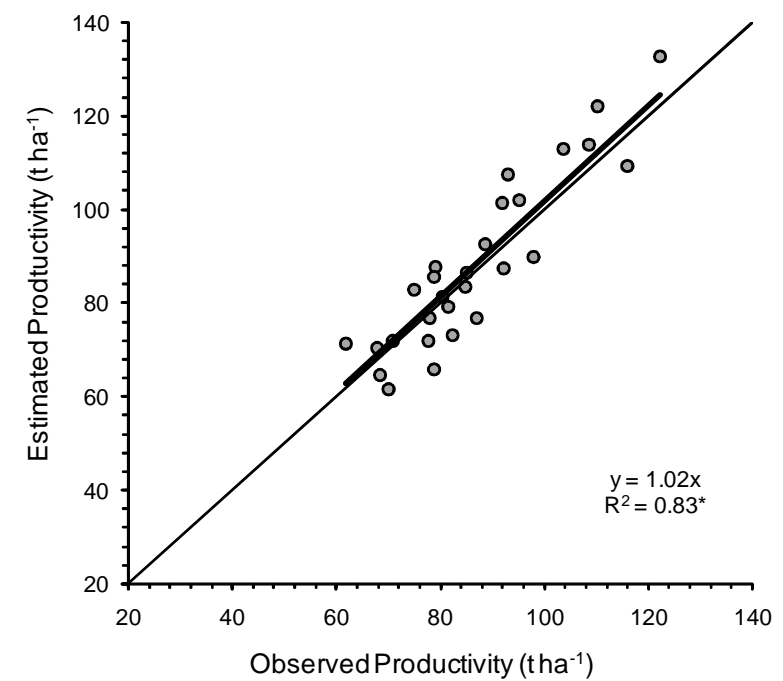

Figure 1 - Relationship between actual productivity, estimated by the AZM model, and observed under field conditions in the Piracicaba region. Adapted from Santos et al. (2006) and Gazzola (2007). *Significant at $1 \%$.

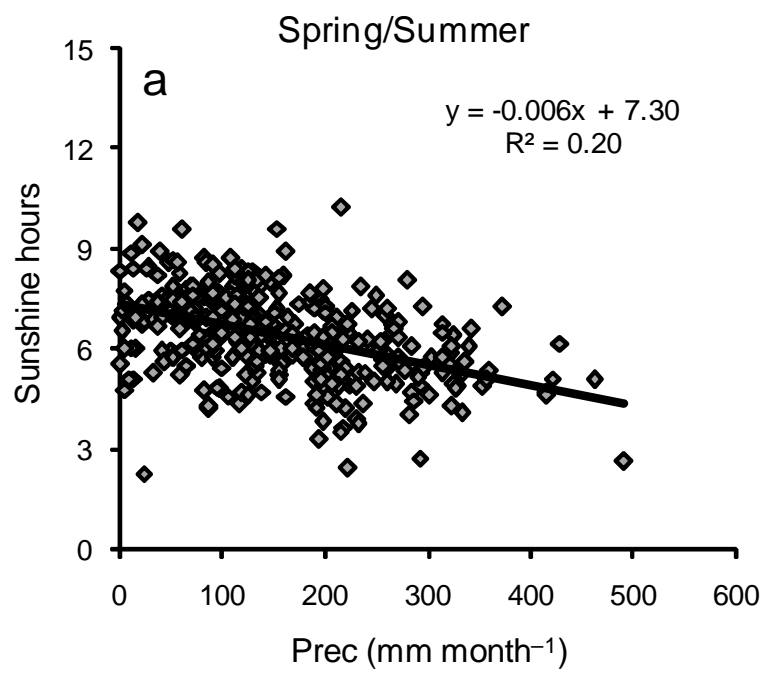

Figure 2 - Relationship between monthly rainfall (Prec) and average daily sunshine hours, during Spring/Summer (a) and Winter/Fall (b) seasons in Piracicaba, SP, Brazil.
Regarding the influence of cloudy conditions on solar radiation, the relationship between monthly rainfall and sunshine hours for Piracicaba was established to determine the effect of changing rainfall on the availability of solar energy for the sugarcane crop in the future scenarios (Figure 2). Even considering the weak relationships between rain and sunshine hours $\left(\mathrm{R}^{2}=0.20\right.$ for Spring/Summer and $\mathrm{R}^{2}=0.23$ for Fall/ Winter) and the high related uncertainty, these relationships were used in the future scenarios to describe the tendency of less/more sunshine hours during the summertime and more sunshine hours during the wintertime, as implied by the possible A1B rainfall estimates (Tables 3 and 4).

A linear increase from 370 ppm (current concentration) to $721 \mathrm{ppm}$ by 2080 was used to evaluate the effect of the increasing $\mathrm{CO}_{2}$ concentration in the atmosphere. The increment in sugarcane productivity caused by that increase was considered to be $0.029 \%$ $\mathrm{ppm}^{-1}$, according to Tubiello et al. (2000).

Scenarios with combinations of increases in temperature $\left(1,2\right.$ and $\left.3^{\circ} \mathrm{C}\right)$, variations in precipitation and sunshine hours, and increases in $\mathrm{CO}_{2}$ concentration in the atmosphere (440, 559, and $721 \mathrm{ppm})$ were used to analyze the sugarcane productivity changes, caused by climate forecasts for the Piracicaba region (Tables 3, 4 and 5), for the years 2020, 2050 and 2080.

The importance of technological advances was also highlighted in this study, since the genetic improvement of crops, associated with adequate management practices, is responsible for the increase in sugarcane productivity seen in recent decades (Figure 3). The considered sugarcane crop technological trend was established from the Automatic Recovery System (SIDRA) database of the Brazilian Institute of Geography and

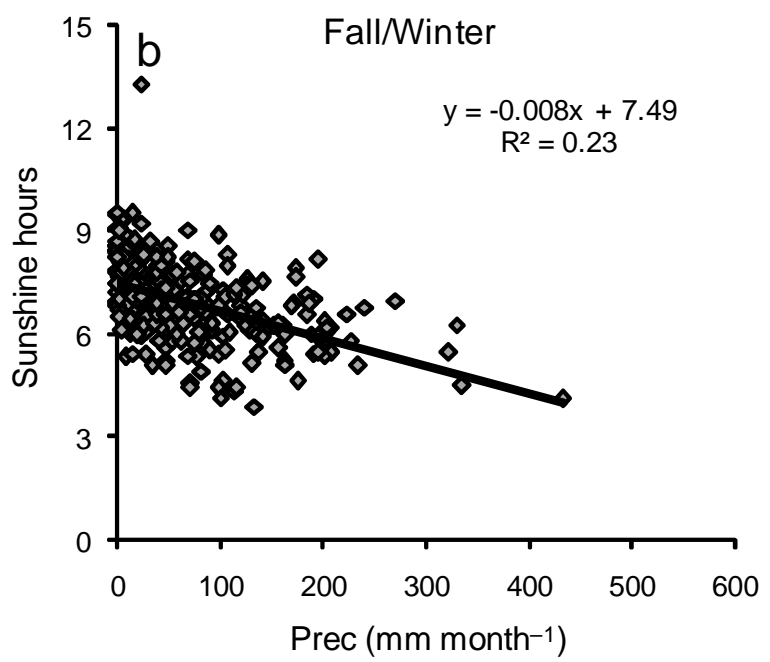


Table 3 - Future climate scenarios with combinations of changes in temperature $(\Delta \mathrm{T})$ and rainfall $(\Delta \mathrm{P})$, according to the prognosis of the IPCC's A1B model.

\begin{tabular}{|c|c|c|c|c|c|c|}
\hline \multirow{2}{*}{ Scenario } & \multirow{2}{*}{ Year } & \multirow{2}{*}{$\Delta \mathrm{T}$} & \multicolumn{4}{|c|}{$\Delta \mathrm{P}$} \\
\hline & & & Spring & Summer & Autumn & Winter \\
\hline & & ${ }^{\circ} \mathrm{C}$ & - & . & $\ldots$ & 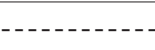 \\
\hline $\mathrm{C} 0$ & 2006 & 0 & 0 & 0 & 0 & 0 \\
\hline $\mathrm{C} 1$ & 2020 & 1 & 0 & -5 & 0 & -5 \\
\hline $\mathrm{C} 2$ & 2020 & 1 & 0 & 0 & 0 & -5 \\
\hline $\mathrm{C} 3$ & 2020 & 1 & 0 & +5 & 0 & -5 \\
\hline $\mathrm{C} 4$ & 2020 & 1 & 0 & -5 & 0 & -10 \\
\hline $\mathrm{C} 5$ & 2020 & 1 & 0 & 0 & 0 & -10 \\
\hline C6 & 2020 & 1 & 0 & +5 & 0 & -10 \\
\hline $\mathrm{C} 7$ & 2020 & 1 & 0 & 0 & 0 & 0 \\
\hline $\mathrm{C} 8$ & 2050 & 2 & 0 & -5 & 0 & -5 \\
\hline C9 & 2050 & 2 & 0 & 0 & 0 & -5 \\
\hline $\mathrm{C} 10$ & 2050 & 2 & 0 & +5 & 0 & -5 \\
\hline C11 & 2050 & 2 & 0 & -5 & 0 & -10 \\
\hline $\mathrm{C} 12$ & 2050 & 2 & 0 & 0 & 0 & -10 \\
\hline $\mathrm{C} 13$ & 2050 & 2 & 0 & +5 & 0 & -10 \\
\hline $\mathrm{C} 14$ & 2050 & 2 & 0 & 0 & 0 & 0 \\
\hline $\mathrm{C} 15$ & 2080 & 3 & 0 & -5 & 0 & -5 \\
\hline $\mathrm{C} 16$ & 2080 & 3 & 0 & 0 & 0 & -5 \\
\hline $\mathrm{C} 17$ & 2080 & 3 & 0 & +5 & 0 & -5 \\
\hline $\mathrm{C} 18$ & 2080 & 3 & 0 & -5 & 0 & -10 \\
\hline C19 & 2080 & 3 & 0 & 0 & 0 & -10 \\
\hline $\mathrm{C} 20$ & 2080 & 3 & 0 & +5 & 0 & -10 \\
\hline $\mathrm{C} 21$ & 2080 & 3 & 0 & 0 & 0 & 0 \\
\hline
\end{tabular}

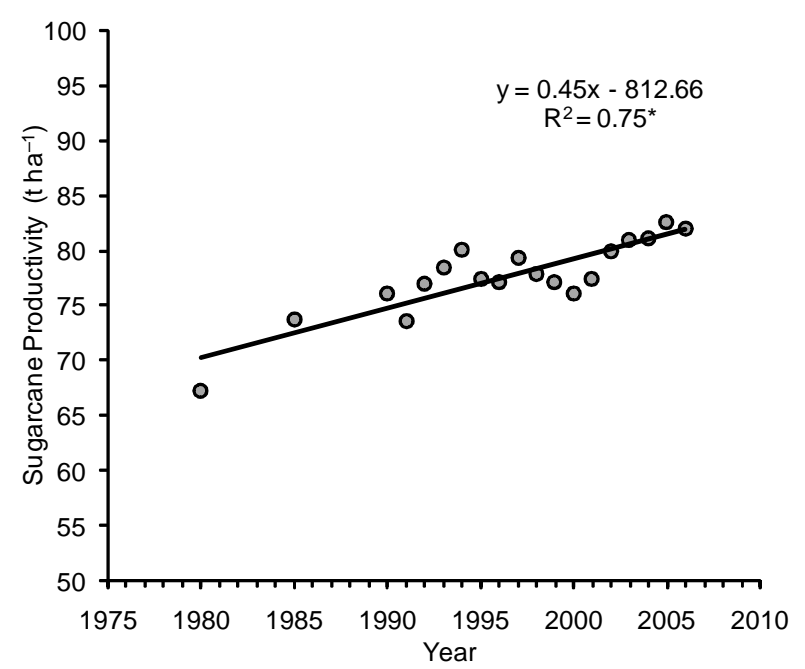

Figure 3 - Technological trend of sugarcane productivity in the State of São Paulo, Brazil, from 1980 to 2006. *Significant at $1 \%$.

Statistics (IBGE, 2007), using the census for 1980 and 1985, and the data from the Municipal Agricultural Production (PAM) database for the period between 1990 and 2006, for the State of São Paulo, Brazil. Based on the linear regression equation obtained between productivity and years, it can be inferred that the productivity increase caused by technological advances was calculated, with an average constant rate of $0.43 \mathrm{t} \mathrm{ha}^{-1}$ per year.

The yield increment caused by technological advances was adopted as constant throughout the analyzed period, considering that new varieties produced by genetic engineering and best management practices developed within the next 70 years will allow the sugarcane crop to have an increasingly better yield efficiency. Under this assumption a yield plateau hypothesis was not adopted for the study period.

\section{Data analysis}

The simulations of sugarcane potential and actual productivities for the Piracicaba region, for an eightyyear period, were performed for each of the established scenarios to determine the sugarcane temporal yield variability under such conditions. This procedure was adopted to obtain the average productivity and its variability, expressed in terms of the standard deviation. Therefore, for each scenario the model was run 
Table 4 - Future climate scenarios with changes in sunshine hours $(\Delta n)$, according to the rainfall prognosis of the IPCC's A1B model.

\begin{tabular}{llrrrr}
\hline \multirow{2}{*}{ Scenario } & Year & \multicolumn{3}{c}{$\Delta$ n } & Winter \\
\cline { 3 - 6 } C0 & & Spring & Summer & Autumn & 0 \\
\hline C1 & 2006 & 0 & 0 & 0 & +4.3 \\
C2 & 2020 & 0 & +1 & 0 & +4.3 \\
C3 & 2020 & 0 & 0 & 0 & +4.3 \\
C4 & 2020 & 0 & -6.5 & 0 & +5.9 \\
C5 & 2020 & 0 & +1 & 0 & +5.9 \\
C6 & 2020 & 0 & 0 & 0 & +5.9 \\
C7 & 2020 & 0 & -6.5 & 0 & 0 \\
\hline C8 & 2020 & 0 & 0 & 0 & +4.3 \\
C9 & 2050 & 0 & +1 & 0 & +4.3 \\
C10 & 2050 & 0 & 0 & 0 & +4.3 \\
C11 & 2050 & 0 & -6.5 & 0 & +5.9 \\
C12 & 2050 & 0 & +1 & 0 & +5.9 \\
C13 & 2050 & 0 & 0 & 0 & +5.9 \\
C14 & 2050 & 0 & -6.5 & 0 & 0 \\
\hline C15 & 2050 & 0 & 0 & 0 & +4.3 \\
C16 & 2080 & 0 & +1 & 0 & +4.3 \\
C17 & 2080 & 0 & 0 & 0 & +4.3 \\
C18 & 2080 & 0 & -6.5 & 0 & +5.9 \\
C19 & 2080 & 0 & +1 & 0 & +5.9 \\
C20 & 2080 & 0 & 0 & 0 & +5.9 \\
C21 & 2080 & 0 & -6.5 & 0 \\
\hline
\end{tabular}

80 times, one time for each year of the 80 -year period to incorporate the climate variability. The productivities were analyzed in two ways: individually, for each type of sugarcane crop (plant crop and ratoon crops); and considering the general productivity, calculated as a function of the usual percentage of each type of sugarcane in the field in a commercial crop (15\% of the area with plant crop, $25 \%$ with early ratoon crop, $39 \%$ with mid ratoon crop, and $21 \%$ with late ratoon crop).

\section{RESULTS AND DISCUSSION}

\section{Impact of future scenarios on potential and actual sugarcane productivity}

The potential productivity for each type of maturity cycle of the sugarcane crop in the future scenarios is forecast to increase when compared to the current scenario (Figure 4). For C0, the potential productivity of the sugarcane plant crop reaches $148 \mathrm{t} \mathrm{ha}^{-1}$, whereas for the sugarcane ratoon crop the potential is $112 \mathrm{t} \mathrm{ha}^{-1}$ for the early cycle, $97 \mathrm{t} \mathrm{ha}^{-1}$ for the medium cycle and $116 \mathrm{t} \mathrm{ha}^{-1}$ for the late cycle. The gen- eral average potential productivity for sugarcane in the Piracicaba region is $112.5 \mathrm{t} \mathrm{ha}^{-1}$.

Considering the future scenarios, the potential productivity of the sugarcane plant crop may range from 168.5 to $170.4 \mathrm{t} \mathrm{ha}^{-1}$ in 2020 (C1 to C7), from 191 to $193 \mathrm{t} \mathrm{ha}^{-1}$ in 2050 (C8 to C14) and from 209.6 to 212.1 $\mathrm{t} \mathrm{ha}^{-1}$ in 2080 (C15 to C21). For sugarcane ratoon crops, the potential productivity for scenarios C1 to C7 (2020) may range from 127.6 to $129.4 \mathrm{t} \mathrm{ha}^{-1}$ for the early cycle, from 111.5 to $113.1 \mathrm{t} \mathrm{ha}^{-1}$ for the mid cycle, and from 131.9 to $133.8 \mathrm{t} \mathrm{ha}^{-1}$ for the late cycle. For 2050, corresponding to scenarios C8 to C14, the potential productivity may increase further, ranging from 147.5 to $149.5 \mathrm{t} \mathrm{ha}^{-1}$ for the early cycle, from 130.3 to $132.1 \mathrm{t} \mathrm{ha}^{-1}$ for the mid cycle, and from 152.1 to $154.2 \mathrm{t} \mathrm{ha}^{-1}$ for the late cycle. Finally, in 2080, scenarios C15 to C21, the ratoon crop potential productivity may reach the following ranges: from 162 to 164 $\mathrm{t} \mathrm{ha}{ }^{-1}$ for the early cycle; from 145 to $146.7 \mathrm{t} \mathrm{ha}^{-1}$ for the mid cycle; and from 167.1 to $169.2 \mathrm{t} \mathrm{ha}^{-1}$ for the late cycle (Figure 4).

Considering the proportion of the areas of each type of sugarcane maturity cycle in the field, the gen- 
Table 5 - Future climate scenarios based on combinations of productivity changes caused by $\mathrm{CO}_{2}$ increases $\left(\triangle\right.$ Prod $\left.\mathrm{CO}_{2}\right)$, according to the prognosis of the IPCC's A1B model (IPCC, 2007) and technological advances ( $\triangle$ Prod $T A)$.

\begin{tabular}{lccc}
\hline \multicolumn{1}{c}{ Scenário } & Year & $\Delta$ Prod $\mathrm{CO}_{2}$ & $\Delta$ Prod TA \\
\hline C0 & 2006 & $\%$ & $\mathrm{t} \mathrm{ha}^{-1}$ \\
\hline C1 & 2020 & +2 & +6.02 \\
C2 & 2020 & +2 & +6.02 \\
C3 & 2020 & +2 & +6.02 \\
C4 & 2020 & +2 & +6.02 \\
C5 & 2020 & +2 & +6.02 \\
C6 & 2020 & +2 & +6.02 \\
C7 & 2020 & +2 & +6.02 \\
\hline C8 & 2050 & +5.4 & +18.92 \\
C9 & 2050 & +5.4 & +18.92 \\
C10 & 2050 & +5.4 & +18.92 \\
C11 & 2050 & +5.4 & +18.92 \\
C12 & 2050 & +5.4 & +18.92 \\
C13 & 2050 & +5.4 & +18.92 \\
C14 & 2050 & +5.4 & +18.92 \\
\hline C15 & 2080 & +10 & +31.82 \\
C16 & 2080 & +10 & +31.82 \\
C17 & 2080 & +10 & +31.82 \\
C18 & 2080 & +10 & +31.82 \\
C19 & 2080 & +10 & +31.82 \\
C20 & 2080 & +10 & +31.82 \\
C21 & 2080 & +10 & +31.82 \\
\hline & & & \\
\hline
\end{tabular}
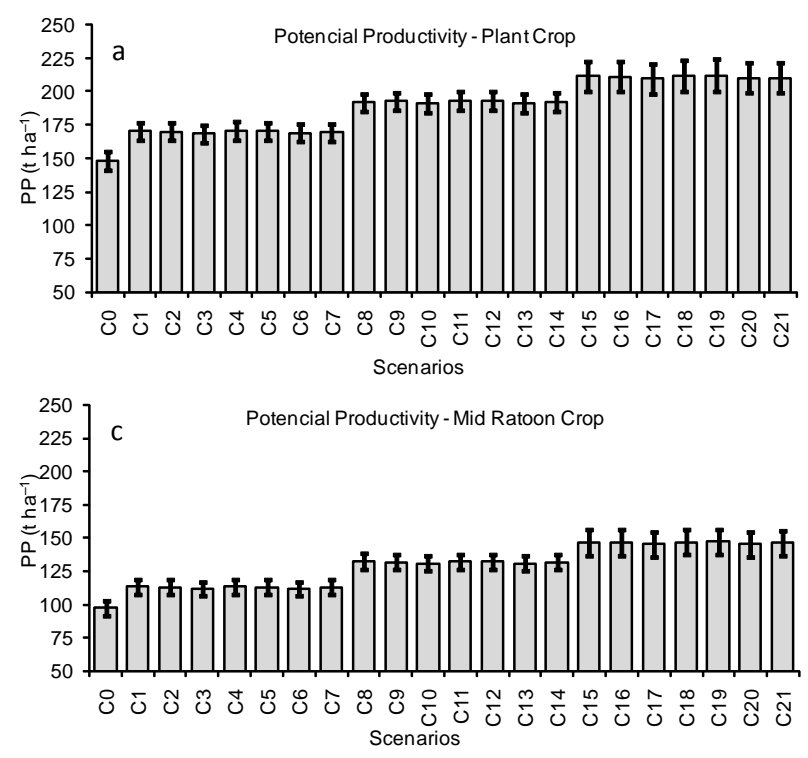

eral potential productivity will change from $112.5 \mathrm{t} \mathrm{ha}^{-1}$ (C0) to the following ranges: from 128.4 to $130.2 \mathrm{t}$ $\mathrm{ha}^{-1}$ in 2020 , from 148.3 to $150.1 \mathrm{t} \mathrm{ha}^{-1}$ in 2050 , and from 163.6 to $165.6 \mathrm{t} \mathrm{ha}^{-1}$ in 2080 (Table 6), which correspond to increases of approximately $15 \%, 33 \%$, and $47 \%$, respectively.

The potential productivity is determined by solar radiation, temperature, photoperiod and genetic characteristics of the crop. As a result, increasingly higher temperatures will cause an increase of the potential productivity, since that variable affects the efficiency of the photosynthetic process. For our study, without considering the other effects, an increase in temperature of 1,2 and $3^{\circ} \mathrm{C}$ resulted respectively in $6.4,12.1$ and $17.0 \%$ yield increments in relation to the present conditions. This can be confirmed by the analysis made by Melo et al. (2007), who stated that the production of dry matter by sugarcane increases with higher temperatures.

An increase in temperature caused by higher $\mathrm{CO}_{2}$ concentration in the atmosphere tends to shorten the growth and development cycles of some C4 species, which may cancel the advantages of the $\mathrm{CO}_{2}$ fertilization (Streck, 2005). This is likely to occur with annual crops, which have their development cycles mainly controlled by air temperature. In the case of a sugarcane crop, this is not a fact since this crop is semi-perennial and its cycle is controlled by farmers who allow the plants to remain in the field for a growth period which ranges from 10 to 24 months (Alfonsi et al., 1987).

The results of potential productivity within each considered time period are very similar (Figure 4),
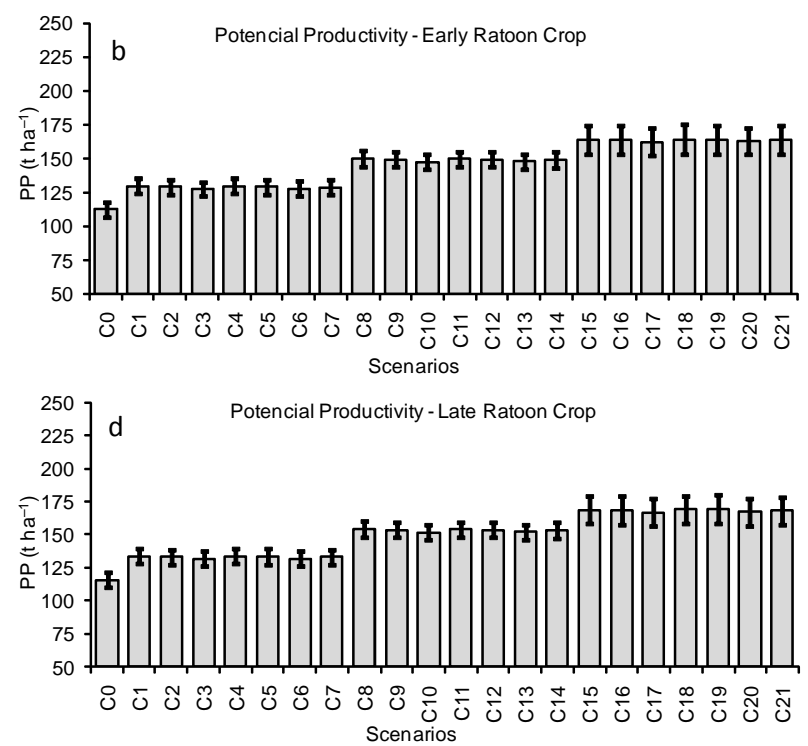

Figure 4 - Potential productivity for sugarcane plant and ratoon (early, mid and late) crops under current conditions (C0) and for different future scenarios (from C1 to C21) in Piracicaba, SP, Brazil. The bars represent the standard deviations for an 80year period. 
which implies that the impacts of the assumed variation due to temperature, $\mathrm{CO}_{2}$ and technology on productivity were higher than the impact of sunshine hours. Whereas increments in yield were from 6 to $17 \%$ due to increases in temperature, from 2 to $10 \%$ due to $\mathrm{CO}_{2}$ and from 6 to $32 \mathrm{tha}^{-1}$ due to technology, the variation in sunshine hours only resulted in yield variations between $-0.28 \%$ and $+0.93 \%$.

The actual productivities, in which the effect of the water deficit is considered, show similar behavior to the potential productivity in the future scenarios (Figure 5). In the current climate conditions (C0), the actual productivity is $110 \mathrm{t} \mathrm{ha}^{-1}$ for the sugarcane plant crop, $83 \mathrm{t} \mathrm{ha}^{-1}$ for the early ratoon crop, $74 \mathrm{t} \mathrm{ha}^{-1}$ for the mid ratoon crop, and $73 \mathrm{t} \mathrm{ha}^{-1}$ for the late ratoon crop. For the future scenarios, the actual productivity of the sugarcane plant crop may range from 122 to $123 \mathrm{t} \mathrm{ha}^{-1}$ in 2020 (C1 to C7), from 139.4 to $140.6 \mathrm{t}$ $\mathrm{ha}^{-1}$ in 2050 (C8 to C14) and from 154.7 to $155.9 \mathrm{t}$ $\mathrm{ha}^{-1}$ in 2080 (C15 to C21). For ratoon crops, the actual productivity for scenarios C1 to C7 (2020) may range from 91.6 to $93 \mathrm{t} \mathrm{ha}^{-1}$ for the early cycle, from 83.5 to $84.4 \mathrm{t} \mathrm{ha}^{-1}$ for the mid cycle, and from 80.2 to $81.4 \mathrm{t} \mathrm{ha}^{-1}$ for the late cycle. For 2050, corresponding to scenarios C8 to C14, the actual productivity may increase, ranging from 108 to $109.4 \mathrm{t} \mathrm{ha}^{-1}$ for the early cycle, from 99.2 to $99.9 \mathrm{t} \mathrm{ha}^{-1}$ for the mid cycle, and from 95.4 to $96.7 \mathrm{t} \mathrm{ha}^{-1}$ for the late cycle. Finally, in 2080, scenarios from C15 to C21, the ratoon crop actual productivity may reach the following ranges: from 121 to $122 \mathrm{t} \mathrm{ha}^{-1}$ for the early cycle; from 112 to 112.7 $\mathrm{t} \mathrm{ha}^{-1}$ for the mid cycle; and 108.2 to $109.3 \mathrm{t} \mathrm{ha}^{-1}$ for the late cycle (Figure 5).

Considering the proportion of the areas of each type of sugarcane maturity cycle in the field, the general actual productivity will change from the present $81 \mathrm{t} \mathrm{ha}^{-1}$ to the following ranges: from 90.1 to $91.2 \mathrm{t}$ $\mathrm{ha}^{-1}$ in 2020, from 106.1 to $107.1 \mathrm{t} \mathrm{ha}^{-1}$ in 2050 , and

Table 6 - General sugarcane potential productivity (PP), considering the proportion of each type of maturity cycle in the field: $15 \%$ with plant crop; $25 \%$ with early ratoon crop; $39 \%$ with mid ratoon crop; and $21 \%$ with late ratoon crop, in Piracicaba, SP, Brazil.

\begin{tabular}{lccccc}
\hline Scenarios 2020 & General PP & Scenarios 2050 & General PP & Scenarios 2080 & General PP \\
\hline C1 & $\mathrm{t} \mathrm{ha}^{-1}$ & & $\mathrm{t} \mathrm{ha}^{-1}$ & & $\mathrm{tha}$ \\
C2 & 130.0 & $\mathrm{C} 8$ & 150.1 & $\mathrm{C} 15$ & 165.3 \\
C3 & 129.8 & $\mathrm{C} 9$ & 149.8 & $\mathrm{C} 16$ & 165.1 \\
C4 & 128.4 & $\mathrm{C} 10$ & 148.3 & $\mathrm{C} 17$ & 163.6 \\
C5 & 130.2 & $\mathrm{C} 11$ & 150.1 & $\mathrm{C} 18$ & 165.4 \\
C6 & 129.9 & $\mathrm{C} 12$ & 149.9 & $\mathrm{C} 19$ & 165.6 \\
C7 & 128.5 & $\mathrm{C} 13$ & 148.4 & $\mathrm{C} 20$ & 163.9 \\
\hline
\end{tabular}
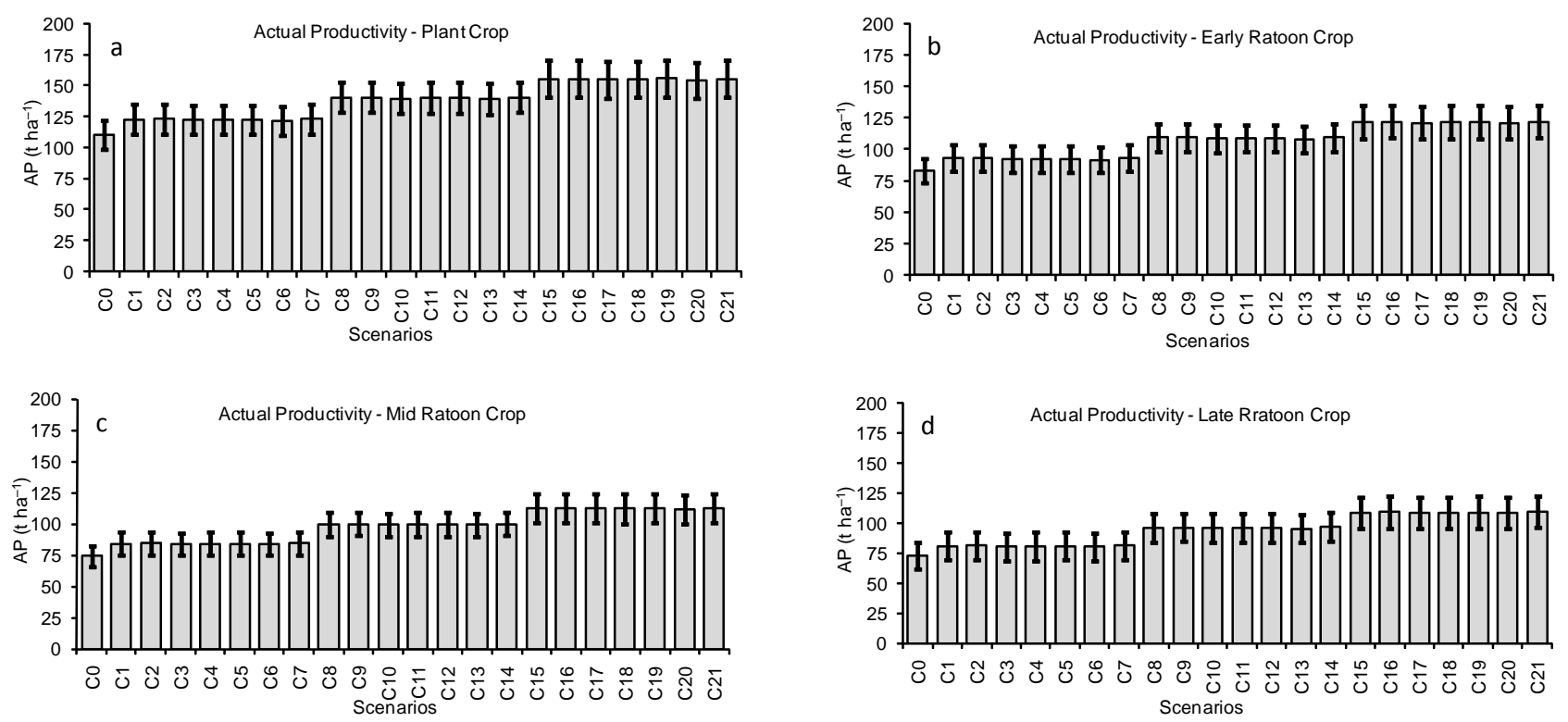

Figure 5 - Actual productivity for sugarcane plant and ratoon (early, medium and late) crops under current conditions and for different future scenarios, in Piracicaba, SP, Brazil. The bars represent the standard deviation for an 80-year period. 
from 119.2 to $120.1 \mathrm{t} \mathrm{ha}^{-1}$ in 2080 (Table 7), which correspond to increases of $12 \%, 32 \%$, and $47 \%$, respectively.

Even considering that the water balance would change in the future scenarios (Table 8), as also highlighted by Salati et al. (2006) and Horikoshi \& Fisch (2007), the effects of increasing water deficit would have less impact on AP than those caused by temperature, $\mathrm{CO}_{2}$ concentration and technological advances. Whereas higher temperatures will increase potential productivity by 6 to $17 \%$ in the future scenarios, the higher water deficits, resulting from increasing potential evapotranspiration, will reduce actual productivity by $1.7 \%$ in 2020 , by $3.2 \%$ in 2050 , and by $4.5 \%$ in 2080 . This weak effect of water deficits on actual yield is explained by the

Table 7 - General sugarcane actual productivity (AP), considering the proportion of each type of maturity cycle in the field: $15 \%$ with plant crop; $25 \%$ with early ratoon crop; $39 \%$ with mid ratoon crop; and $21 \%$ with late ratoon crop, in Piracicaba, SP, Brazil.

\begin{tabular}{lccccc}
\hline Scenarios 2020 & General AP & Scenarios 2050 & General AP & Scenarios 2080 & General AP \\
\hline & $\mathrm{t} \mathrm{ha}^{-1}$ & & $\mathrm{t} \mathrm{ha}^{-1}$ & & $\mathrm{t} \mathrm{ha}^{-1}$ \\
C1 & 90.9 & $\mathrm{C} 8$ & 107.0 & $\mathrm{C} 15$ & 119.8 \\
C2 & 91.1 & $\mathrm{C} 9$ & 107.0 & $\mathrm{C} 16$ & 120.1 \\
C3 & 90.4 & $\mathrm{C} 10$ & 106.3 & $\mathrm{C} 17$ & 119.5 \\
C4 & 90.7 & $\mathrm{C} 11$ & 106.6 & $\mathrm{C} 18$ & 119.6 \\
C5 & 90.8 & $\mathrm{C} 12$ & 106.7 & $\mathrm{C} 19$ & 120.0 \\
C6 & 90.1 & $\mathrm{C} 13$ & 106.1 & $\mathrm{C} 20$ & 119.2 \\
C7 & 91.2 & $\mathrm{C} 14$ & 107.1 & $\mathrm{C} 21$ & 120.1 \\
\hline
\end{tabular}

Table 8 - Annual rain (P), potential evapotranspiration (ETP), actual evapotranspiration (ETA), water deficit (WD) and water surplus (WS), obtained by the 10-day normal water balance, for the current scenario and for the scenarios of climate changes, in Piracicaba, SP, Brazil.

\begin{tabular}{lccccc}
\hline Scenarios & P & ETP & ETA & WD & WS \\
\hline C0 & 1348.3 & 1486.3 & 1226.6 & 259.6 & 116.2 \\
\hline C1 & 1307.1 & 1586.9 & 1264.6 & 322.3 & 59.5 \\
C2 & 1336.9 & 1586.9 & 1264.6 & 322.3 & 79.6 \\
C3 & 1366.7 & 1586.9 & 1264.6 & 322.3 & 99.8 \\
C4 & 1314.2 & 1586.9 & 1259.4 & 327.5 & 59.5 \\
C5 & 1331.6 & 1586.9 & 1259.4 & 327.5 & 79.6 \\
C6 & 1361.4 & 1586.9 & 1259.4 & 327.5 & 99.8 \\
C7 & 1342.1 & 1586.9 & 1269.7 & 317.2 & 79.6 \\
\hline C8 & 1307.1 & 1677.6 & 1298.7 & 378.9 & 34.1 \\
C9 & 1336.9 & 1677.6 & 1298.7 & 378.9 & 54.2 \\
C10 & 1366.7 & 1677.6 & 1298.7 & 378.9 & 74.4 \\
C11 & 1314.2 & 1677.6 & 1293.5 & 384.1 & 34.1 \\
C12 & 1331.6 & 1677.6 & 1293.5 & 384.1 & 54.2 \\
C13 & 1361.4 & 1677.6 & 1293.5 & 384.1 & 74.4 \\
C14 & 1342.1 & 1677.6 & 1303.9 & 373.7 & 54.2 \\
\hline C15 & 1307.1 & 1759.0 & 1324.7 & 434.3 & 12.6 \\
C16 & 1336.9 & 1759.0 & 1327.2 & 431.8 & 32.4 \\
C17 & 1366.7 & 1759.0 & 1327.2 & 431.8 & 52.6 \\
C18 & 1314.2 & 1759.0 & 1321.6 & 437.4 & 12.6 \\
C19 & 1331.6 & 1759.0 & 1321.9 & 437.1 & 32.4 \\
C20 & 1361.4 & 1759.0 & 1321.9 & 437.1 & 52.6 \\
C21 & 1342.1 & 1759.0 & 1332.4 & 426.6 & 32.4 \\
\hline & & & & \\
\hline
\end{tabular}


small differences observed in the relative water deficit (1 - ETa/ETc), used in equation 13. It varied, on average, from 0.175 for the current conditions (C0) to 0.203 in 2020 (C1 to C7), 0.226 in 2050 (C8 to C14), and 0.246 in 2080 (C15 to C21). Such small effects of water deficits on AP are controlled not only by the changes in ETP and rain, but also by the time of the year when they occur, since the sugarcane crop will respond with different intensities to water deficit depending on its growth phase. While water deficit causes intense yield losses during sprouting, establishment and the period of high vegetative growth, it is favorable during the maturation process having less impact on yield (Doorenbos \& Kassam, 1994).

The sugarcane yield loss from potential to actual productivity [(1-AP/PP)*100] for the current scenario (C0) is $28 \%$. It will increase to $30 \%$ for scenarios C1 to C7, and to $29 \%$ for scenarios C8 to C14. For scenarios C15 to C21, such yield loss will decrease to $27 \%$. These results reinforce the weak impact of the future water deficit scenarios on productivity, as mentioned before.

The results of this study, which include the effect of climate change and technology advances, indicate increases in the potential and actual productivities of sugarcane in every future scenario for the Piracicaba region, in relation to the current conditions. However, these data should be considered as only an indication of what may happen in future situations, since the evaluation of the impacts of climate changes on agricultural productivity by crop simulation models is very uncertain. The main reason for caution is related to the climate uncertainty under higher $\mathrm{CO}_{2}$ concentrations, as observed by Challinor et al. (2005). These authors also observed that yield is more affected by perturbation of climate parameters than crop model parameters in both the present-day and doubled $\mathrm{CO}_{2}$ climates; crop transpiration efficiency was crucial for crop model uncertainty in both present-day and doubled $\mathrm{CO}_{2}$ climates; and the response of crop development to mean temperature contributed little to uncertainty in the present-day simulations but was among the largest contributors under doubled $\mathrm{CO}_{2}$.

The direct use of climate change estimates from large-scale models at a regional level was made without a downscaling technique. Such an approach, using climate change values calculated at large spatial resolutions with general circulation models, as presented by IPCC, 2007, could bring large biases to the projections at a regional scale, making the results even more uncertain.
Consequences of the future scenarios on the sugarcane sector considering climate changes in the Piracicaba region

The world supply of energy is mainly based on fossil fuels. Their use on a world-wide scale tends to exhaust the sources, leaving a critical condition for future generations. Additionally, the use of fossil fuels is responsible for serious local pollution problems and for most of the global emission of gases that cause the greenhouse effect.

The current challenge is to find renewable sources of energy and to increase the efficiency of their generation and use. In Brazil, the sugarcane industry presents an important opportunity for the replacement of fossil fuels. An increase in sugarcane productivity as a consequence of climate change may have important impacts on the sugarcane sector, such as the possibility that the crop will expand to regions now unfeasible for production, due to low temperatures that inhibit the growth of the crop (Zullo Júnior et al., 2006; Melo et al., 2007). An increase in temperature will entail additional beneficial effects, such as an increase in productivity, since the air temperature will be closer to the ideal values for the crop, positively affecting the photosynthetic efficiency. An increase in the $\mathrm{CO}_{2}$ concentration will be another stimulus for the sugarcane plant, since it responds to this fertilization effect with an increase in biomass production (Souza, 2007).

Along with environmental factors, technological advances play an important role in the development of the sugarcane crop, since genetic improvement of the plant, associated to adequate management practices, is responsible for an increase in productivity of $0.43 \mathrm{t}$ $\mathrm{ha}^{-1}$ per year. This produces an additional 6, 19 and $32 \mathrm{t} \mathrm{ha}^{-1}$ of yield for 2020, 2050 and 2080 respectively, which represents around 35, 51 and $61 \%$ of the respective total projected increase in general potential crop productivity. All these factors may lead to an optimization of the land use, that is, a higher production over smaller areas.

\section{CONCLUSIONS}

The agrometeorological model was a very useful tool to describe the effect of climate change and technological advance on sugarcane productivity. There will be a beneficial effect of forecasted climate changes on sugarcane productivity, due to the expected increases in temperature and $\mathrm{CO}_{2}$ concentration. Technological advances, which include development of new varieties and best management practices, will also contribute to enhance general potential productivity, representing 35\% of the yield gains in 2020, 51\% in 2050 
and $61 \%$ in 2080. Changes in solar radiation and rainfall will have less effect on sugarcane productivity, which is fortunate because forecasts of these variables have very high uncertainty. The PP will increase by $15 \%$ in relation to the present condition in 2020, by $33 \%$ in 2050 and by $47 \%$ in 2080 . Regarding the AP, the increase observed in PP will mostly compensate for the negative effect of an increasingly deficit of water. AP will increase by $12 \%$ in relation to the present condition in 2020 , by $32 \%$ in 2050 and by $47 \%$ in 2080. Although the results show increases in sugarcane potential and actual productivities in all future scenarios, they have to be considered with caution, due to the high degree of uncertainty related to the limitations of the used agrometeorological model, the uncertainties of the future climate, and to the large spatial resolution of the adopted climate change projections.

\section{ACKNOWNLEDGMENTS}

The authors are thankful to CAPES, for the scholarship for the first author, to CNPq, for the fellowship for the second author, and to the anonymous reviewer for the important suggestions which contributed to the improvement of the manuscript. To Dr. Terry Gillespie, University of Guelph, Canada, for reviewing the manuscript and for the helpful suggestions.

\section{REFERENCES}

ALFONSI, R.R.; PEDRO JÚNIOR, M.J.; BRUNINI, O.; BARBIERI, V. Condições climáticas para cana-de-açúcar. In: PARANHOS, S. B. (Coord.) Cana-de-açúcar: cultivo e utilização. Campinas: Fundação Cargill, 1987. v.1, p.42-55.

ASSAD, E.D.; PINTO, H.S.; ZULLO JÚNIOR, J.; ÁVILA, A.M.H. Impacto das mudanças climáticas no zoneamento agroclimático do café no Brasil. Pesquisa Agropecuária Brasileira, v.39, p.1057-1064, 2004.

BARBIERI, V.; TUON, R.L. Metodologia para estimativa da produção potencial de algumas culturas. Piracicaba: ESALQ/Departamento de Física e Meteorologia. 1992. $17 p$.

BARBIERI, V.; TERUEL, D.A.; SILVA, J.G.; SANTOS, R.M.N. Balanço hídrico de Thornthwaite e Mather modificado para estimativa de deficiência nas culturas. In: CONGRESSO BRASileiro DE AGROMETEOROLOGIA, 10., Piracicaba, 1997. Anais. Piracicaba: Sociedade Brasileira de Agrometeorologia; 1997. p.587-589.

CAMARGO, A.P.; MARIN, F.R.; SENTELHAS, P.C.; PICINI, A.G. Ajuste da equação de Thornthwaite para estimar a evapotranspiração potencial em climas áridos e superúmidos, com base na amplitude térmica. Revista Brasileira de Agrometeorologia, v.7, p.251-257, 1999.

CHALLINOR, A.J.; WHEELER, T.R.; SLINGO, J.M.; HEMMING, D. Quantification of physical and biological uncertainty in the simulation of the yield of a tropical crop using present day and doubled CO2 climates. Philosophical Transactions of the Royal Society B, v.360, p.2085-2094, 2005.
CERRI, C.E.P.; SPAROVEK, G.; BERNOUX, M.; EASTERLING, W.E.; MELILLO, J.M.; CERRI, C.C. Tropical agriculture and global warming: impacts and mitigations options. Scientia Agricola, v.64, p.83-99, 2007.

DOORENBOS, J.; KASSAM, A.H. Efeito da água no rendimento das culturas. Campina Grande: UFPB, 1994. 306p. (Estudos FAO Irrigação e Drenagem).

FISCHER, G.; SHAH, M.; VELTHUIZEN, H. van. Climate change and agricultural vulnerability. Johannesburg: IIASA. 2002. 152p.

GAZZOLA, S.T. Caracterização climática e os efeitos da variabilidade das condições meteorológicas nas produtividades potencial e real da cana-de-açúcar em Piracicaba (SP). Piracicaba: USP/ESALQ, 2007. 61p. (Relatório de Estágio Profissionalizante - Engenharia Agronômica).

GOLDEMBERG, J.; LUCON, O. Energia e meio ambiente no Brasil. Estudos Avançados, v.21, p.7-20, 2007.

HORIKOSHI, A.S.; FISCH, G. Balanço Hídrico atual e simulações para cenários climáticos futuros no município de Taubaté, SP, Brasil. Revista Ambiente e Água: An Interdisciplinary Journal of Applied Science, v.2, p.33-46, 2007.

INSTITUTO BRASILEIRO DE GEOGRAFIA E ESTATÍSTICA IBGE. Available in www.sidra.ibge.gov.br. Accessed 23 Jun. 2007.

INTERGOVERNMENTAL PANEL ON CLIMATE CHANGE.IPCC. Climate change 2007: the physical science basis. Summary for Policymakers. Working Group I. Available at: http://ipccwg1.ucar.edu/wg1/Report/AR4WG1_Pub_SPM-v2.pdf.. Accessed 01 Jun. 2007.

MARENGO, J.A. Mudanças climáticas globais e seus efeitos sobre a biodiversidade: caracterização do clima atual e definição das alterações climáticas para o território brasileiro ao longo do século XXI., Brasília: Ministério do Meio Ambiente, 2006. v.26, 212 p. (Série Biodiversidade).

MARIN, F.R.; LOPES-ASSAD, M.L.; ASSAD, E.D.; VIAN, C.E.; SANTOS, M.C. Sugarcane crop efficiency in two growing seasons in São Paulo State, Brazil. Pesquisa Agropecuária Brasileira, v.43, p.1449-1455, 2008.

MELO, S.B.; GALON, L.; SOUZA, E.F.M.; REZENDE, M.L.; RENATO, N.S. Aquecimento global e um estudo da produtividade potencial da cana-de-açúcar para a região de São Paulo. Caatinga, v.20, p.10-17, 2007.

PEREIRA, A.R.; ANGELOCCI, L.R.; SENTELHAS, P.C. Agrometeorologia: fundamentos e aplicações práticas. Guaíba: Agropecuária, 2002. 478p.

ROLIM, G.S.; SENTELHAS, P.C.; BARBIERI, V. Planilha no ambiente Excel para os cálculos de balanços hídricos: normal, seqüencial, de cultura e de produtividade real e potencial. Revista Brasileira de Agrometeorologia, v.6, p.133-137, 1998.

ROLIM, G.S.; SENTELHAS, P.C.; UNGARO, M.R.G. Análise de risco climático para a cultura do girassol, em algumas localidades de São Paulo e do Paraná, usando os modelos DSSAT/OILCROPSUN e FAO. Revista Brasileira de Agrometeorologia, v.9, p.91-102, 2001.

SALATI, E.; SANTOS, A.A.; KLABIN, I. Temas ambientais relevantes. Estudos Avançados, v.20, p.107-127, 2006.

SANTOS, M.C.; SENTELHAS, P.C.; MARIN, F.R. Calibração do modelo agrometeorológico da FAO para a estimativa da produtividade potencial e real da cana-de-açúcar (Saccharum spp). In: Simpósio Internacional de Iniciação Científica da Universidade de São Paulo, 2006, Piracicaba. XIV SIICUSP. Anais. São Paulo : Universidade de São Paulo, 2006. v.1. CD-ROM.

SIMON, C.; DeFRIES, R.S. Uma terra, um futuro. São Paulo: Makron Books, 1992. 189p.

SOUZA, A.P. A cana-de-açúcar e as mudanças climáticas: efeitos de uma atmosfera enriquecida em $\mathrm{CO}_{2}$ sobre o crescimento, desenvolvimento e metabolismo de carboidratos de Saccharum spp. Campinas: UNICAMP, 2007. 85p. Dissertação Dissertação (Mestrado).

STRECK, N.A. Climate change and agroecosystems: the effect of elevated atmospheric $\mathrm{CO}_{2}$ and temperature on crop growth, development, and yield. Ciência Rural, v.35, p.730-740, 2005. 
TERUEL, D.A.; BARBIERI, V.; FERRARO JÚNIOR, L.A. Sugarcane leaf area index modeling under different soil water conditions. Scientia Agricola, v.54, p.39-44, 1997.

THORNTHWAITE, C.W. An approach toward a rational classification of climate. Geographical Review, v.38, p.5594, 1948.

THORNTHWAITE, C.W.; MATHER, J.R. The water balance. Publications in Climatology. Philadelphia: Drexel Institute of Technology, 104p. 1955.

TUBIELlO, F.N.; DONATELli, M.; ROSENZWEIG, C.; STOCKLE, C.O. Effects of climate change and elevated $\mathrm{CO}_{2}$ on cropping systems: model predictions at two Italian locations. European Journal of Agronomy, v.13, p.179-189, 2000.
ZULLO JÚNIOR, J.; PINTO, H. S.; ASSAD, E.D. Impact assessment study of climate change on agricultural zoning. Meteorological Applications, v.1, p.69-80, 2006.

Received February 29, 2008

Accepted February 17, 2009 